\title{
Harvesting geo-spatial data on coastal fish assemblages through coordinated citizen science
}

Støttrup, Josianne G.; Kokkalis, Alexandros; Brown, Elliot John; Olsen, Jeppe; Kærulf Andersen, Stine; Pedersen, Eva Maria

\section{Published in:}

Fisheries Research

Link to article, DOI:

10.1016/j.fishres.2018.07.015

Publication date:

2018

Document Version

Peer reviewed version

Link back to DTU Orbit

Citation (APA):

Støttrup, J. G., Kokkalis, A., Brown, E. J., Olsen, J., Kærulf Andersen, S., \& Pedersen, E. M. (2018). Harvesting geo-spatial data on coastal fish assemblages through coordinated citizen science. Fisheries Research, 208, 8696. https://doi.org/10.1016/j.fishres.2018.07.015

\section{General rights}

Copyright and moral rights for the publications made accessible in the public portal are retained by the authors and/or other copyright owners and it is a condition of accessing publications that users recognise and abide by the legal requirements associated with these rights.

- Users may download and print one copy of any publication from the public portal for the purpose of private study or research.

- You may not further distribute the material or use it for any profit-making activity or commercial gain

- You may freely distribute the URL identifying the publication in the public portal 
Harvesting geo-spatial data on coastal fish assemblages through coordinated citizen science.

Støttrup, J.G, Kokkalis, A., Brown, E.J., Olsen, J., Kærulf Andersen, S., Pedersen, E.M.

Technical University of Denmark, National Institute of Aquatic Resources, Kemitorvet, Building 202, 2800 Kongens Lyngby, Denmark

\section{Abstract}

In response to repeated complaints from recreational and commercial coastal fishermen about declining fishing opportunities in inner Danish waters, focus was directed to inshore fish stocks. However, without data targeting inshore areas, it was not possible to investigate potential changes in fish distribution or abundances, or their causes. As a first step, a voluntary catch registration system was initiated in 2002, in collaboration with locally organized recreational fishermen. Using citizen science as a methodology, scientists and the fishermen developed a protocol for data collection, which the fishermen then implemented. The aim was to establish regular monitoring of fish catches from gill net and fyke net fisheries in coastal waters around Denmark in order to provide data that could inform management. After three years, during which time recreational fishermen could use their own gear and fish where they normally fished, the data was evaluated. As a result, the fishing method was switched in 2005 to fixed gears and fixed positions, to enable comparison between areas, years and season. The project has been very successful in recruiting highly motivated fishermen, who register their entire catch regularly. The time-series of data spans more than a decade and covers over 16,000 instances of fishing. The data from this project are now being used to create coastal fish indicators for managers to assess environmental status at a regional 
scale. Here we present an analysis of a subset of the data on one species, the European flounder (Platichthys flesus), to illustrate how the spatial and seasonal coverage can be utilized further for investigation of coastal ecosystems and to inform management.

Keywords: recreational fishing, fish monitoring, coastal fish

\section{Introduction}

Monitoring and management of coastal ecosystems along exposed coasts, bays, fjords, estuaries and lagoons are regularly the focus of environmental policy in Europe (European Parliament and Council of the European Union, 2000; Ferreira et al., 2007), the United States (Karr, 1981) and Australia (Commonwealth of Australia, 2006), among others. This focus reflects the relative intensity and diversity of human activities impacting upon these enclosed and nearshore ecosystems (Airoldi and Beck, 2007). The anthropogenic pressures that act on nearshore marine habitats have cumulative impacts (Halpern et al., 2007; Lotze, 2006; O’Meara et al., 2017). The variety and scale of these impacts influence the distribution of coastal fish (Dutz et al., 2016), the productivity of juvenile habitats (Vasconcelos et al., 2007) and many other important life history stages (Seitz et al., 2014). Coastal fish, subject to these impacts, provide many ecosystem services which both support ecosystem function and benefit humans (Hattam et al., 2015). However, without data on coastal fish assemblages, it may be difficult to generate changes in management of coastal systems and gradual losses in ecosystem services may go unheeded.

\subsection{Cultural services}

In terms of cultural services, coastal fish are exploited by both small-scale commercial and recreational fisheries for the provision of food and recreational value. Small-scale coastal fisheries 
are poorly understood, often due to a lack of available data (Natale et al., 2015). Whilst small-scale commercial fisheries and recreational fishers share a common resource, data on recreational fish catches are even more sparse. In Denmark, both groups of fishers have noted declines in coastal catches of several fish species (Støttrup et al., 2014; V. Gram, pers. comm.). Reports of such declines from recreational fishermen's organizations were the original impetus for this collaborative study.

\subsection{Information services}

Coastal fish assemblages react to a broad range of anthropogenic pressures (Barausse et al., 2011; Hallett et al., 2012; Henriques et al., 2013) and can thus provide important information as biological indicators of the coastal ecosystem status. As indicators, the state of coastal fish assemblages provide a service. The value of this service is reflected in the European Union's Water Framework Directive (WFD) (Borja, 2005). Here it is stated that fish should be included in the suite of biological indicators applied to an integrated environmental assessment of pressures within coastal ecosystems (Borja et al., 2008; Ferreira et al., 2007; Korpinen et al., 2012). Fish as indicators for system health have also been developed for estuarine systems in the USA (Deegan et al., 2016).

Around the Baltic Sea, countries such as Sweden (Olsson et al., 2012) and Estonia (HELCOM, 2017) have established fisheries-independent coastal fish monitoring regimes, which can both provide local stock information and inform coastal fish indicators. In other Baltic states, monitoring practices have been sporadic due to the high cost of implementation and fluctuations in financial support. Alternatively, monitoring is dependent on small-scale commercial fisheries data, e.g. Finland (HELCOM, 2015). In Denmark, no coastal fish monitoring has been established by relevant authorities. As required by the EU Data Collection Framework introduced in 2001 and recently amended in 2016 (EU, 2016), estimates of recreational catches for several species should be 
3

provided annually. Species requirements vary across regions (Hyder et al., 2018). In Denmark, estimates of recreational catches are provided for (Atlantic cod (Gadus morhua), European eel (Anguilla anguilla) and sea trout (Salmo trutta)), but these rely on off-site interview surveys (Olesen and Storr-Paulsen, 2015)

\subsection{Citizen science}

Citizen sciences engages the public and enhances their participation in marine resource management (Vann-Sander et al., 2016). Engaging citizens or a focus group of citizens allows the provision of data on higher spatial and temporal scales than under present day monitoring programs in for example the Baltic Sea region (http://www.helcom.fi/Lists/Publications/Guidelines \%20for\%20Coastal\%20fish\%20Monitoring\%20of\%20HELCOM.pdf; accessed 03.05.2018). Citizen science is becoming more commonplace with increased recognition of its value among academia and in national and international organizations (McKinley et al., 2017). For example, focus groups consisting of divers were engaged to provide new knowledge about rare coral reef species (Chin, 2014) or in another instance student focus groups documented invasive species (Delaney et al., 2008). Citizen engagement, however, requires good communication and relations between citizens and scientists/managers and the best outcomes of citizen science are derived from cases where there was mutual respect and benefit for the parties involved. The impact of citizen science on policy making and management seems to depend on the perception of data quality and there is therefore a need to ensure data of a quality that it can be taken up by management (Hyder et al., 2015; Underwood and Chapman, 2006; Vann-Sander et al., 2016).

In this study, we demonstrate the potential for citizen science to provide long-term data on the occurrence and abundance of fish species in coastal areas around Denmark. We aimed to develop a 
method to harvest geo-spatial data on fish assemblages through working with the local recreational fishermen who provided data using standard gear, fixed positions and standardized fishing protocols. To demonstrate the advantage of the spatial and temporal coverage provided by this citizen science approach, we focused on catch data of European flounder (Platichthys flesus). The current mechanisms for registering and reporting catches are discussed and advantages and pitfalls highlighted.

\section{Materials and methods}

\subsection{Key-fisher engagement}

A volunteer-based program was established in 2002 in Denmark in collaboration with two national recreational fishermen's organizations. With their collaboration, it was possible to recruit “key” recreational fishermen (hereafter key-fishers) who were willing to commit time to regular fishing in order to provide data on coastal fish. At the first meeting with the newly enlisted keyfishers, the ground rules for the fishery were agreed upon. The key-fishers were instructed on how to fill out the catch report and were provided with information on species identification. Annual meetings were held with the volunteer key-fishers to discuss results, problems (gear, fish identification, fishing regulations), review consistent reporting errors, or inform on current events such as new invasive species. Letters were sent to the volunteers at the start of the season, during summer in lieu of the annual meeting and towards the end of the year, together with a small token of appreciation. Key-fishers who had not provided completed catch sheets during a year were contacted at the end of the year to discover the cause and agree on a solution. New key-fishers were recruited in the beginning of each year, where required, to replace or improve the distribution of key-fishers across different areas. 


\subsection{Fishery}

For the period 2002-2004, the fyke net data only were used as the gear used for this type of fishing was similar to the gear used in the subsequent years. The eel fyke net (80/7 with $8 \mathrm{~m}$ net between the two traps; Daconet, 2018a) was the standard type used. The gill nets used during 20022004 varied too significantly in design to provide comparable data. In 2005, flounder gill nets (monofilament, mesh size: 65 mm, mounted length: 39 m; Daconet, 2018b) were introduced as standard to allow for catch per unit effort (CPUE) comparisons between areas and over time. The program funded the equipment and the chair of one of the fishermen's organizations controlled the purchase and distribution, including on-going replacement of worn out or lost gear.

Three gill nets were deployed in sequence, in near-shore locations around sunset and collected at sunrise utilizing small vessels and resulting in soak times of six to twelve hours depending on the season. The fyke nets (three sets) were set for approximately $48 \mathrm{~h}$. The time of deployment and collection was registered. Each key-fisher had a set position for each gear type and fished up to three times per month throughout the year. Key-fishers were strongly encouraged to fish during the first 10 days of the month but some fishing was undertaken outside of this period due to weather constraints and other obligations. The whole catch was registered to the species or family level. To aid in fish identification, each key-fisher was given a Danish handbook with pictures and descriptions of local fish species (Muus and Nielsen, 2006). Total length of all individuals was measured to the nearest $\mathrm{cm}$. In cases where large numbers were caught, the whole catch was divided into sub-samples and one sub-sample was randomly chosen to count number of fish. In these cases, only the length of the largest and smallest fish was provided.

Catches and other relevant information were recorded on standardized hardcopy forms, which were mailed to the institute for data entry and quality assurance. In 2014, a web-portal was established for key-fishers to enter their catch-data directly into the institute's database. This web- 
portal also provided data validation at the time of entry to ensure that fields such as date and time of gear deployment and recovery, observation of invasive species and other observations were recorded. Data validation also provided key-fishers the opportunity to correct erroneous entries by questioning ambiguous values for catch records. Registering and use of the web-portal was voluntary and was rolled out gradually.

Each key-fisher was provided with a temperature logger (ONSET HOBO, model UA-001-08), which was attached to a buoy marking the fishing position. In this way, the loggers monitored the water temperature at the fishing position continuously. Where losses from removal of these loggers were high, the loggers were attached to the fishing gear and thus registered water temperature during the fishing event only. Recordings from all loggers were downloaded each year, either at an annual meeting or during the winter non-fishing period.

\subsection{Data analyses}

To demonstrate the value of this citizen science data, we focused on flounder catch data. The catch data was organized into 21 areas based on water boundaries established by the Danish Maritime Safety Administration and aggregated to ensure that there was sufficient coverage of fishers per area. CPUE was calculated as the catch divided by the soak time over an aggregating period, e.g. year or month, in a specific area, i.e.

$$
\operatorname{CPUE}_{\mathrm{a}, \mathrm{t}}=\frac{1}{\mathrm{n}} \sum_{i=1}^{n} c_{i} / f_{i}
$$

where $c_{i}$ denotes the catch in numbers and $f_{i}$ the soaking time that was recorded in fishing instance $i$; $\mathrm{n}$ is the total number of fishing instances in the current area $a$ and time aggregation $t$. We report the CPUE in numbers over $48 \mathrm{~h}$ of fishing per fyke net and over $12 \mathrm{~h}$ of fishing for gill nets, as these were representative soak times for the two gears. Linear regressions of yearly log transformed CPUE of flounder were fitted to identify temporal trends in two of the areas Roskilde Fjord and Isefjord (9 fishers), and Sejerø Bay (6 fishers). The existence of a monotonous temporal trend was 
additionally tested with a Mann-Kendal test. Generalized additive models (GAM; Wood, 2006)

were used to fit the seasonal patterns CPUE along with the overall temporal trends

$\log \left(I_{i}\right)=f_{1}\left(m_{i}\right)+f_{2}\left(t_{i}\right)+U(i)_{\text {fisher }}+e_{i}$

where $I_{i}$ is the CPUE, $m$ is the month of the year, $t$ is the cumulative time in days from the beginning of the time series, $f_{1}$ is a cyclic cubic regression spline, $f_{2}$ is a one dimensional thin plate spline, and $e_{i}$ are independent normally distributed random variables. The individual key-fishers are included as random effects in the model and are represented as penalized regression terms. To test the hypothesis of an existing overall temporal trend a model was fitted without the second smooth $f_{2}\left(t_{i}\right)$ and the Akaike Information Criterion (AIC) and an F-test were used for model selection. Information on local temperature was obtained from the temperature loggers that had been placed on the sea bottom near one of the fishing positions in the area. Exemplary logger data from two areas were plotted over three years for visual comparisons with monthly CPUE data for flounder.

\section{Results}

From 2005 to 2016, between 27 and 84 key-fishers participated in the project each year providing 16,445 fishing instances. These key-fishers fished with either gill nets, fyke nets or both. Tables S1-S4 in the supplementary material show the number of fishers and fishing instances per year and gear. The fishing effort increased in 2008 from less than 1000 to greater than 1600 instances each year until 2011. Since then it has varied between 1300 and 1500 instances (Fig. 1). The distribution of the fishing positions was mainly focused in the fjords and coastal areas of the inner Danish waters (Fig. 2). Most key-fishers fished from approximately April to November, although some fished year-round except during periods of winter ice cover. Every third year a report was compiled on the data from the previous three years but also included trend data for the 
whole monitoring period (Kristensen et al., 2014; Sparrevohn et al., 2009; Støttrup et al., 2017, 2012). Each report was presented at one of the annual meetings and was sent by mail to those unable to attend.

Over the entire period, 96 species were caught in both gears, with 88 species being registered in fyke nets and 46 in gill nets (Table 1). By numbers per effort, flounder was the species most frequently caught in gill nets throughout the whole project period (Fig.3). Conversely, eelpout (Zoarces viviparous) was the most frequently caught species in fyke nets at the beginning of the project, but was surpassed by the invasive round goby (Neogobius melanostomus). By 2016, round goby was caught at more than double the rate of eelpout, in spite of it only being caught in a small proportion of fished areas (5 out of 21 areas). The first catches of round goby were registered in Bornholm in 2010, with the registrations expanding westward to Fehmarn Belt and northward to Smålandsfarvandet and Køge Bay.

Mean annual CPUE from gill net catches of flounder are available from 20 of the 21 areas (Fig. 4). For the fyke net catches, the mean annual CPUE data was plotted for three years longer but for two fewer areas (Fig. 5). These annual data consist of catches from fishers who persisted throughout the length of the project as well as those who left and joined throughout. New areas were introduced following two separate campaigns to recruit key-fishers specifically for these areas. The area excluded from Fig. 4 was Smålandsfarvandet due to the recent recruitment of key-fishers, in 2016, and the three areas excluded from Fig. 5 were due to the key-fishers in these areas only using gill nets. It is evident from these figures that some areas exhibit positive temporal trends in CPUE, for example "Roskilde Fjord and Isefjord” and "Sejerø Bay” gill net data (Fig. 4). Linear regressions of the yearly CPUE for flounder in gill nets from these areas confirm the positive trend for Roskilde Fjord and Isefjord (F-test, $F_{1,10}=10.58, p<0.01$, adjusted $R^{2}=0.47$, Fig. 6a and Fig. S1 in supplementary material), but not for Sejerø Bay (F-test, F1,9 $=4.914, \mathrm{p}>0.05$, adjusted $R^{2}=0.28$, 
Fig. $6 \mathrm{~b}$ and Fig. S2 in supplementary material). The Mann-Kendal test shows a significant trend in monthly CPUE for Roskilde Fjord and Isefjord ( $\tau=0.14, p<0.001)$, but not in Sejerø Bay ( $\tau=0.062, p>0.05$ ), where the trend does not seem to be linear. GAM models applied to CPUE data show a significant seasonal component and an overall positive temporal trend for both areas (Fig. 6c, d). The full model including both smooths is preferred (Roskilde: AIC = 3553.2, Deviance explained $=41 \%$, Sejerø: AIC $=2379.5$, Deviance explained $=51.4 \%$ ) over the model excluding overall temporal trend (Roskilde: AIC = 3769.0, F-test, $F=15.023, \mathrm{p}<0.0001$; Sejerø: AIC = 2604.0, F-test, $F=15.759, \mathrm{p}<0.0001)$. Visual inspection of the model residuals does not indicate any violation of the model assumptions, i.e. normality and homoscedasticity (Fig. S3 and S4 in supplementary material).

Flounder are caught during the winter months in the fjord, although at lower CPUE than during the summer months, and peaking during springtime (Fig. 7). A similar peak around June is observed in Sejerø Bay in all three years but no data are available over the winter months. The temperature data, worked up from the loggers provided, show that the spring water temperature in Roskilde Fjord and Isefjord warms up earlier and reaches higher values than in the open coastal bay of Sejerø (Fig. 7).

\section{Discussion}

With limited resources for coastal fish monitoring, engaging citizens or a focus group of capable and motivated citizens, can provide a cost-effective means of data collection and even increase spatial and temporal scales (Fairclough et al., 2014). It is possible that the coastal marine ecology and environmental sciences can benefit to the same degree as the analogous terrestrial sciences, which have been highly successful in engaging citizens (Kosmala et al., 2016). The level of coordination and communication achieved during this program has proven sufficient to ensure its 
persistence. Whilst there have been challenges in this approach to data collection, they were easily overcome once properly identified. Furthermore, the citizen science approach taken here has increased social capital by prompting on the one hand a deeper understanding of scientific work and on the other, greater appreciation of local experience. This has led to increased knowledge and awareness of the marine and coastal environment through interaction between the scientists and the focus group of citizens.

\subsection{Data application}

Several species are both commonly caught and easy to identify. With the CPUE time-series, seasonal and geographical population trends are monitored over large spatial and temporal scales. In terrestrial systems, volunteer collected data are widespread and have proven effective for exploring spatial variation in phenological trends in birds (Newson et al., 2016) and for establishing early warning systems on climate induced changes in biodiversity (Barnard et al., 2017). The data from citizen science projects help fill data gaps in understudied areas (Hyder et al., 2016). In the marine environment, good coverage survey data on fish abundance is available (e.g. in Europe; ICES, 2017) but this data does not extend to the shoreline and excludes fjords and estuaries. Combining coastal fish data from studies such as this with the offshore data from established scientific fishing surveys provides new opportunities to explore questions on fish ecology, fish population dynamics and life-history connectivity. Further, the impact of climate change on coastal fish distributions can be explored at large spatial scales, where important processes not detectable at local scales may dominate dynamics.

\subsubsection{Long term trends}

The CPUE data on flounder was used to develop fish indicators for HELCOM (HELCOM, 2017). The data can be classified as fisheries independent, because the key-fishers are requested to fish within a narrow period on a monthly basis using standardized gear. 
Annual CPUE data has also been used by fisheries managers to address local conflicts between anglers targeting sea trout and gill net recreational fishermen. The latter were attributed high bycatches of sea trout and thus blamed for the absence of this species of fish in the area (first author observations and M. Christoffersen, pers. comm.).

\subsubsection{Seasonal trends}

The sampling undertaken by the key-fishers spans the entire year. The data provides information on the timing and location of juvenile migration into summer growth habitats (or nurseries) and the temporal and spatial overlap with adult conspecifics in coastal habitats. These data have the potential to explore how environmental drivers influence the timing of these juvenile migrations.

Shallow nearshore areas constitute juvenile growth habitats (nurseries) for many fish species, particularly flatfish (Able and Fodrie, 2015; Gibson, 1994). Flounder, in particular, occupies the very shallow habitats that provide good conditions for growth, survival and recruitment (Andersen et al., 2005; Carl et al., 2008; Florin et al., 2009; Martinsson and Nissling, 2011). Without a citizen science approach it may only be possible to study such seasonal events in a limited geographic area and for a limited number of years (e.g. Freitas et al., 2016; Souza et al., 2013). Flatfish, such as plaice Pleuornectes platessa (Freitas et al., 2016) and flounder (Muus, 1967) move offshore to deeper waters during autumn, although a smaller percentage of the juvenile flounder are observed to winter in the shallow estuaries (Muus, 1967). With the key-fisher data, we can confirm the overwintering of flounder in the shallow coastal fjords and bays, where fishing has taken place year round. The percentage that remain in the fjord is, however, uncertain. The lower catches during winter could either be due to reduced metabolic scope, hence mobility (Holt and Jørgensen, 2015) and thus lower encounter rate with the passive gear, or due to movement of a larger portion of the population out of the fjord (Muus, 1967). 
The temporal distribution of the data combined with more sophisticated modelling may help increase the accuracy of the fish indicators used to assess the health of coastal systems (HELCOM, 2017). Only the data from August were used for the indicators in order to align the sampling time with monitoring programs conducted by the other HELCOM contracting parties from around the Baltic Sea. However, the coastal waters around Denmark are very shallow and water temperature in the bays and fjords are highest in June - August. Temperature optimum for flounder is $20^{\circ} \mathrm{C}$, with a temperature tolerance range to $26^{\circ} \mathrm{C}$ (Freitas et al., 2007). High summer temperatures approaching, or even surpassing, the upper limits of tolerance may cause flounder to move offshore to cooler waters as was suggested for the absence of plaice in the tidal flats of the German Wadden Sea (Teal et al., 2012). Alternatively, flounder activity may be downregulated with a reduction in metabolic scope (Duthie, 1982) and thus less likely to encounter the passive gear. Sampling over several months may improve accuracy in assessing the development of the population over the years. In combination with a model that considers seasonal variation, a significant positive trend in the development of the flounder population was observed for Sejerø Bay that could not otherwise be observed using a linear regression or only the data for August.

\subsubsection{Spatial coverage}

The broad temporal and spatial coverage provides a good overview of the species most commonly found in inner Danish waters. The dominant species flounder, eel and eelpout were caught in all areas and in all years, reflecting their physiological tolerance to the high fluctuations in salinity and temperature that characterize the shallow coastal areas of the inner Danish waters (Madsen and Højerslev, 2009). Site-specific detailed data, provided by the temperature loggers, show differences in the progressive spring warming of coastal waters in the bays or fjords that are not detected via other monitoring or modelling techniques. These local differences in the timing and absolute increases of temperature may be important for an early start of, and for prolonging, the 
summer growth season. Risk of mortality, especially in the early life stages, decreases with increasing fish size (Beverton and Iles, 1992), meaning warmer local temperatures may convey a two-fold benefit of increased growth and survival.

The broad geographic distribution of the sampling also allows for early detection and mapping of invasive species. The round goby was first noticed in the Gulf of Gdansk in 1990 (Skóra and Stolarski, 1996), where it established itself before spreading further into the Baltic Sea. The first specimen was observed around the island of Bornholm in 2008 (Azour et al., 2015) and started occurring in the key-fisher data in 2010. It is only caught in the fyke nets and even though it is only caught in a few areas in the southeastern part of Denmark and Bornholm, it is caught in such abundance that it now tops the catch records, in terms of number. It continues to spread into the Danish inner waters at a rate of approximately 30 km per year (Azour et al., 2015; Behrens et al., 2017). As of 2016, the key-fisher data shows round goby inhabiting the southern part of the Sound (Faxe Bay) and the Great Belt (Smålandsfarvandet).

\subsubsection{Cultural services}

Whilst small-scale commercial fishers and recreational fishers share a common resource, the former are often limited in their exploitation by quotas set by managers considering scientific advice (output controls) and the latter only by a range of effort restrictions (input controls). In areas with restricted commercial quotas, catches from the recreational sector may thus be proportionally high (Olesen and Storr-Paulsen, 2015) and be ecologically significant, counteracting the effects of commercial fishery management (Hyder et al., 2018; McPhee et al., 2002). Only commercial catches are included in most stock assessments. High and unreported recreational catches may therefore, in some areas hinder our ability to sustainably manage fish stocks. For example, in Germany recreational catches of cod in the western Baltic Sea were estimated to constitute up to $70 \%$ of the German commercial cod landings (Strehlow et al., 2012). Marine recreational fishing is 
gaining interest as an important source of income for national economies (Hyder et al., 2018; Toivonen et al., 2004). There is growing concern about the increasing effort within the recreational fisheries, which rival commercial catches for many fish stocks including depleted or threatened stocks (Coleman et al., 2004; Olesen and Storr-Paulsen, 2015). In Denmark, estimates of recreational catches are only conducted for a few species (cod, eel and sea trout) and rely on off-site interview surveys (Olesen and Storr-Paulsen, 2015). In order to improve estimates of recreational catches, the ongoing project REKREA is combining eel CPUE from the key-fisher data with estimates of recreational effort, but the need to include recreational catches in stock assessment may lead to new measures being introduced to register all recreational catches.

\subsection{Challenges}

\subsubsection{Fish identification}

The accuracy of fish identification varied among the volunteers. Several species are easily recognizable and familiar to the key-fishers, such as the most common flatfish flounder, plaice, sole Solea solea and turbot Psetta maxima and species such as cod, eel and eelpout. The higher taxonomic categories were generally easier to identify especially if physical characteristics differed substantially. There was a tendency for participants to misidentify rarely occurring species, species with limited distributions and invasive species, which they had not yet encountered. In many cases, pictures were taken, or fish were frozen for later expert verification or identification. The species that were often problematic were sculpins (Cottoidea), gurnards (Triglidae), wrasses (Labridae), gobies (Gobidae) and some gadoids (Gadidae). Certain species could be ruled out; for example three -bearded rockling (Gaidropsarus vulgaris) does not spawn around Denmark and generally only larger specimens of this species are caught (Muus and Nielsen, 2006; Henrik Carl, pers. comm.). It can easily be confused with four-bearded rockling (Enchelyopus cimbrius) or fivebearded rockling (Ciliata mustela). From the size of the fish, it could be deduced that the specimens 
registered were most likely not three-bearded rockling and were corrected to rockling spp. For other species, expert judgement based on likelihood of occurrence relative to species distribution was applied. A few participants are retired professionals, whose species recognition skills can be relied upon. However, even for these participants, some species remain difficult to identify without specific equipment, and are registered at the family level, e.g. the small gobies (Gobidae). For these reasons, the data collected is not recommended for monitoring biodiversity. Fish identification courses were held with the key-fishers in 2015 and 2016 targeting those species that were difficult to identify.

\subsubsection{Selectivity of gear}

No single gear type is considered universal. Trawls are the main gear type used in fishing surveys for fish assessments (e.g. International Bottom Trawl Survey), but these gear types are not easy to apply in coastal areas due to the presence of biogenic habitats or other technical reasons. Survey gill nets and fyke nets are proposed for monitoring the relative abundance of indicator species in Baltic Sea coastal areas (Neuman et al., 1999). These gears are static and catches rely on fish mobility during soak times. Due to different levels of activity throughout a day, catch rates in these passive gears likely vary. In the preliminary analyses presented here, we do not account for this. However, potential solutions may be found through considering CPUE on a "net-night” basis, or calculating CPUE on a per hour basis but independently for night and day periods.

Data on fish species and species population structure is limited by the gear selectivity of the gill net used. In this case, where only one-sized gill nets were used (65 mm), juveniles, small bodied or eel-like species were under- or not represented. The gear is highly selective towards maximizing catches of the legally sized flounder, which is above $25.5 \mathrm{~cm}$ in the Kattegat area and $23 \mathrm{~cm}$ in the Belt Seas and western Baltic Sea area. Information on gill net selection for European flounder is not available, but if data for other flatfish species are applied, the maximal selection should be around 
six or seven times the bar length (Holst and Moth-Poulsen, 1995) which would be at fish sizes of 20-23 cm. From 2005-2016, less than $7 \%$ of all the flounder caught in gill nets each year measured $<23 \mathrm{~cm}$. A similar result was obtained on American plaice (Hippoglossoides platessoides) with gill nets of $68 \mathrm{~mm}$ mesh size, where $<3 \%$ of the catches were below the maximal selection size (Hovgård, 1996). This could be due to either larger fish being randomly entangled in the gear or that the gill net selectivity for flatfishes needs more consideration. Since catchability of the smaller individuals is low, it is reasonable to assume that catches of the smaller flounder would be highly variable. To compensate for this, CPUE for flounder $>14 \mathrm{~cm}$ was used to generate the HELCOM fish indicators (HELCOM, 2017).

Fyke nets are rarely used for long-term monitoring (Hinz, 1989). However, fyke nets sample eellike species and juveniles of many species such as flounder and cod. Furthermore, in most areas of this study the fyke nets caught a higher number of species than the gill nets.

\subsubsection{Other sources of bias.}

Standard fishing gear and a protocol developed in collaboration with the key-fishers were implemented to reduce bias. However, bias cannot be eliminated and occurs for example, in the uneven number of key-fishers in each area, resulting in variable effort. This is further exacerbated by intermittent leave from the project due to health issues or other obligations inevitably experienced by the volunteer key-fishers.

\subsection{Social capital}

In order for a citizen science project to be successful and to maintain its longevity, there needs to be a mutual benefit for all involved (Vann-Sander et al., 2016). This is what underpins social capital. For the scientist and managers, the focus group (in this case the recreational fishers) could provide useful data with the strengths and disadvantages as discussed above and apparently typical of this type of monitoring (Danielsen et al., 2009). Distinctive to this type of monitoring (Danielsen 
et al., 2009), the costs to participating fishermen is considerable as each contributes with volunteer hours as well as fuel and other materials. Although no comprehensive social science study has as yet been conducted to demonstrate tangible benefits and understand motivation for their long-term participation, anecdotal evidence reveals a number of aspects. One major change has been the shift from public complaints from the recreational and commercial coastal fishermen to capacity building and participation in problem solving. Capacity building is best gained from citizen science projects where locals are involved in data interpretation and its uses, but can also be gained from the type of monitoring described in this study (Danielsen et al., 2009). In this case, citizens impacted by a situation channeled their energies to data collection, and to finding sustainable solutions through working collaboratively with the scientists. Capacity building was generated through annual meetings held in September each year, with various lectures on requested marine science topics as well as other invited lectures on safety at sea and other relevant issues. Further, one-on-one interviews were held with all involved. This communication resulted in growing awareness of the importance of a healthy coastal system and how their behavior may impact the system, providing a basis for change in attitudes in local communities (Danielsen et al., 2009). From the interviews, the scientists gained awareness of local problems, which initiated several projects. An example of this was the Nørre Fjord project, which aimed to restore a fjord area affected by historic sand mining activities, confounded by more recent eutrophication (Kristensen et al., 2015; Poulsen et al., 2012). The project has provided these key fishers with a contact point to scientists where they could discuss or obtain advice on local environmental concerns.

A requisite for participation in the project was full compliance to national fishing regulations. This led to key-fishers becoming ambassadors for responsible recreational fishing. Additionally, following several discussions on safety at sea in small vessels, key-fishers became ambassadors for safety at sea, endorsed by a commitment to use life jackets whilst on the water. The increase in 
social capital, as a result of this project is thus reflected in the improved knowledge base for all parties, increased communication between fishermen and scientists, greater trust, collaboration and participation in science projects aimed at resolving local environmental problems and the creation of a stewardship ethic.

Several key-fishers have contributed to the project since its outset in 2002. Through this project, key fishers are able to double their fishing efforts. In some areas, a larger fishing effort allows them to catch a reasonable number of minimum size fish for family consumption (they are not allowed to sell their catch). The annual token gifts are much appreciated but, in our view, the publication of a paper report every third year that acknowledges their efforts and the regular use of data by scientists in their advice to management are the main motivational factors to continue to contribute to science. It is viewed by these authors that regular, open communication with the volunteers is pivotal for continued engagement. A social science study would, however, be needed to document the fishermen's motivation to join and remain involved in the project, the benefits and social capital gained and potential behavioral changes.

\section{Conclusion}

The citizen science approach taken in this study has not only provided data on coastal fish in areas previously not considered in standard surveys but has also provided data of higher temporal resolution and over a spatial scale not possible to attain with institute monitoring resources. This study has provided data and findings to inform national evidence based policy advice, and helped meet international monitoring obligations. It has generated spin-off research projects and continues to inform research on fundamental ecological concepts. The key-fishers have ensured the success of this project and in the process become ambassadors for sustainable coastal environments, responsible fishing and safety at sea. We, the authors, hope that our description and findings 
encourage others to consider broader societal engagement in their research and that this paper helps in overcoming some of the initial challenges of establishing such a project.

\section{Acknowledgements}

The authors would like to express a large appreciation for the efforts of Vagn Gram (former chair of Danish Amateur Fishers Association (DAFF), co-founder of this project). Furthermore, our deepest thanks go to the numerous volunteer fishers engaged throughout the project and the supporting chairs of DAFF and Danish Recreational Fishers Federation (DFF). We thank Peter Rask Møller, Marcus Anders Krag and Henrik Carl, Natural History Museum of Denmark, for teaching the first fish identification courses. We thank Dr. Christina Gillgren for her assistance with the social science aspects of this paper and with a review of the English text and Kieran Hyder for the many helpful and constructive comments to the manuscript. Funding for this project was provided by the Ministry of Environment and Food of Denmark through the Danish Marine Coastal Fisheries Management Program (Marin Fiskepleje).

References.

Able, K.W., Fodrie, F.J., 2015. Distribution and dynamics of habitat use by juvenile and adult flatfishes, in: Gibson, R.N., Nash, R.D., Geffen, A.J. (Eds.), Flatfishes: Biology and Exploitation: Second Edition. John Wiley and Sons Ltd., pp. 242-282. https://doi.org/10.1002/9781118501153.ch10

Airoldi, L., Beck, M.W., 2007. Loss, status and Trends for Coastal Marine Habitats of Europe. Oceanogr. Mar. Biol. An Annu. Rev. 45, 345-405. https://doi.org/Book_Doi $10.1201 / 9781420050943$ 
Andersen, A.K., Schou, J., Sparrevohn, C.R., Nicolajsen, H., Støttrup, J.G., 2005. The quality of release habitat for reared juvenile flounder, Platichthys flesus, with respect to salinity and depth. Fish. Manag. Ecol. 12, 211-219. https://doi.org/10.1111/j.1365-2400.2005.00444.x

Azour, F., van Deurs, M., Behrens, J., Carl, H., Hüssy, K., Greisen, K., Ebert, R., Møller, P.R., 2015. Invasion rate and population characteristics of the round goby Neogobius melanostomus: Effects of density and invasion history. Aquat. Biol. 24. https://doi.org/10.3354/ab00634

Barausse, A., Michieli, A., Riginella, E., Palmeri, L., Mazzoldi, C., 2011. Long-term changes in community composition and life-history traits in a highly exploited basin (northern Adriatic Sea): The role of environment and anthropogenic pressures. J. Fish Biol. 79, 1453-1486. https://doi.org/10.1111/j.1095-8649.2011.03139.x

Barnard, P., Altwegg, R., Ebrahim, I., Underhill, L.G., 2017. Early warning systems for biodiversity in southern Africa - How much can citizen science mitigate imperfect data? Biol. Conserv. 208, 183-188. https://doi.org/10.1016/j.biocon.2016.09.011

Behrens, J.W., Van Deurs, M., Christensen, E.A.F., 2017. Evaluating dispersal potential of an invasive fish by the use of aerobic scope and osmoregulation capacity. PLoS One 12, 1-19. https://doi.org/10.1371/journal.pone.0176038

Beverton, R.J.H., Iles, T.C., 1992. I1. Comparison of mortality rates and construction of life table for 0-group plaice. Netherlands J. Sea Res. 29, 49-59. https://doi.org/10.1016/00777579(92)90007-2

Borja, A., 2005. The European water framework directive: A challenge for nearshore, coastal and continental shelf research. Cont. Shelf Res. 25, 1768-1783. https://doi.org/10.1016/j.csr.2005.05.004

Borja, A., Bricker, S.B., Dauer, D.M., Demetriades, N.T., Ferreira, J.G., Forbes, A.T., Hutchings, P., Jia, X., Kenchington, R., Marques, J.C., Zhu, C., 2008. Overview of integrative tools and 
methods in assessing ecological integrity in estuarine and coastal systems worldwide. Mar. Pollut. Bull. 56, 1519-1537. https://doi.org/10.1016/j.marpolbul.2008.07.005

Carl, J.D., Sparrevohn, C.R., Nicolajsen, H., St??ttrup, J.G., 2008. Substratum selection by juvenile flounder Platichthys flesus (L.): Effect of ephemeral filamentous macroalgae. J. Fish Biol. 72, 2570-2578. https://doi.org/10.1111/j.1095-8649.2008.01866.x

Chin, A., 2014. "Hunting porcupines”: Citizen scientists contribute new knowledge about rare coral reef species. Pacific Conserv. Biol. 20, 48-53.

Coleman, F.C., Figueira, W.F., Ueland, J.S., Crowder, L.B., 2004. The impact of United States recreational fisheries on marine fish populations. Science (80-. ). 305, 1958-1960. https://doi.org/10.1126/science.1100397

Commonwealth of Australia, 2006. A Guide to the Integrated Marine and Coastal Regionalisation of Australia Version 4.0. [WWW Document]. Dep. Environ. Heritage, Canberra, Aust. URL http://www.environment.gov.au/resource/guide-integrated-marine-and-coastal-regionalisationaustralia-version-40-june-2006-imcra (accessed 9.28.17).

Daconet, 2018a. Daconet [WWW Document]. URL https://www.daconet.com/standardcatalogue/fykes-and-pots/eel-fyke/dbl-aaleruse-80-7-m-8mtr-rad-staalb-knudeloestbagg-nr-5dh (accessed 4.13.18).

Daconet, 2018b. Daconet [WWW Document]. URL https://www.daconet.com/standardcatalogue/fishing-nets/mounted-nets/plaice-nets/hobby-fishermen/mont-roedspaettegarn-0-2465mm-8-ma-2400kn (accessed 4.13.18).

Danielsen, F., Burgess, N.D., Balmford, A., Donald, P.F., Funder, M., Jones, J.P.G., Alviola, P., Balete, D.S., Blomley, T., Brashares, J., Child, B., Enghoff, M., Fjeldså, J., Holt, S., Hübertz, H., Jensen, A.E., Jensen, P.M., Massao, J., Mendoza, M.M., Ngaga, Y., Poulsen, M.K., Rueda, R., Sam, M., Skielboe, T., Stuart-Hill, G., Topp-Jørgensen, E., Yonten, D., 2009. Local 
participation in natural resource monitoring: A characterization of approaches. Conserv. Biol. 23, 31-42. https://doi.org/10.1111/j.1523-1739.2008.01063.x

Deegan, L.A., Finn, J.T., Ayvazian, S.G., Ryder-Kieffer, C.A., Buonaccorsi, J., 2016. Development and Validation of an Estuarine Biotic Integrity Index. Estuaries 20, 601-617.

Delaney, D.G., Sperling, C.D., Adams, C.S., Leung, B., 2008. Marine invasive species: Validation of citizen science and implications for national monitoring networks. Biol. Invasions 10, 117128. https://doi.org/10.1007/s10530-007-9114-0

Duthie, G.G., 1982. The respiratory metabolism of temperature-adapted flatfish at rest and during swimming activity and the use of anaerobic metabolism at moderate swimming speeds. J. Exp. Biol. 97, 359-373.

Dutz, J., Støttrup, J.G., Stenberg, C., Munk, P., 2016. Recent trends in the abundance of plaice Pleuronectes platessa and cod Gadus morhua in shallow coastal waters of the Northeastern Atlantic continental shelf - a review. Mar. Biol. Res. 0, 1-12. https://doi.org/10.1080/17451000.2016.1210806

EU, 2016. Commission Implementing Decision (EU) 2016/1251 of 12. July 2016 adopting a multiannual Union programme for the collection, management and use of data in the fisheries and aquaculture sectors for the period 2017-2019, 2016/4329.

European Parliament and Council of the European Union, 2000. Directive 2000/60/EC of the European Parliament and of the council of 23 October 2000 establishing a framework for community action in the field of water policy [WWW Document]. URL http://eurlex.europa.eu/legal-content/EN/ALL/?uri=CELEX:32000L0060 (accessed 10.19.17).

Fairclough, D. V, Brown, J.I., Carlish, B.J., Crisafulli, B.M., Keay, I.S., 2014. assessments with citizen science. https://doi.org/10.1038/srep07249

Ferreira, J.G., Vale, C., Soares, C. V., Salas, F., Stacey, P.E., Bricker, S.B., Silva, M.C., Marques, 

J.C., 2007. Monitoring of coastal and transitional waters under the E.U. Water Framework Directive. Environ. Monit. Assess. 135, 195-216. https://doi.org/10.1007/s10661-007-9643-0

Florin, A.B., Sundblad, G., Bergström, U., 2009. Characterisation of juvenile flatfish habitats in the Baltic Sea. Estuar. Coast. Shelf Sci. 82, 294-300. https://doi.org/10.1016/j.ecss.2009.01.012

Freitas, V., Campos, J., Fonds, M., Van der Veer, H.W., 2007. Potential impact of temperature change on epibenthic predator-bivalve prey interactions in temperate estuaries. J. Therm. Biol. 32, 328-340. https://doi.org/10.1016/j.jtherbio.2007.04.004

Freitas, V., Witte, J.I.J., Tulp, I., Veer, H.W. Van Der, 2016. Shifts in nursery habitat utilization by 0-group plaice in the western Dutch Wadden Sea. J. Sea Res. 111, 65-75. https://doi.org/10.1016/j.seares.2015.12.011

Gibson, R.N., 1994. Impact of habitat quality and quantity on the recruitment of juvenile flatfishes. Netherlands J. Sea Res. 32, 191-206. https://doi.org/10.1016/0077-7579(94)90040-X

Hallett, C.S., Valesini, F.J., Clarke, K.R., Hesp, S.A., Hoeksema, S.D., 2012. Development and validation of fish-based, multimetric indices for assessing the ecological health of Western Australian estuaries. Estuar. Coast. Shelf Sci. 104-105, 102-113. https://doi.org/10.1016/j.ecss.2012.03.006

Halpern, B.S., Selkoe, K.A., Micheli, F., Kappel, C. V., 2007. Evaluating and ranking the vulnerability of global marine ecosystems to anthropogenic threats. Conserv. Biol. 21, 13011315. https://doi.org/10.1111/j.1523-1739.2007.00752.x

Hattam, C., Atkins, J.P., Beaumont, N., Börger, T., Böhnke-Henrichs, A., Burdon, D., De Groot, R., Hoefnagel, E., Nunes, P.A.L.D., Piwowarczyk, J., Sastre, S., Austen, M.C., 2015. Marine ecosystem services: Linking indicators to their classification. Ecol. Indic. 49, 61-75. https://doi.org/10.1016/j.ecolind.2014.09.026

HELCOM, 2017. Abundance of coastal fish key species. HELCOM core indicator report [WWW 
Document]. http://www.helcom.fi/baltic-sea-trends/indicators/abundance-of-key-coastal-fishspecies.

HELCOM, 2015. Guidelines for coastal fish monitoring sampling methods of HELCOM. Helsinki, Finland.

Henriques, S., Pais, M.P., Batista, M.I., Costa, M.J., Cabral, H.N., 2013. Response of fish-based metrics to anthropogenic pressures in temperate rocky reefs. Ecol. Indic. 25, 65-76. https://doi.org/10.1016/j.ecolind.2012.09.003

Hinz, V., 1989. Monitoring the fish fauna in the Wadden Sea with special reference to different fishing methods and effects of wind and light on catches. Helgolander Meeresuntersuchung 43, 447-459.

Holst, R., Moth-Poulsen, T., 1995. Numerical recipes and statistical methods for gillnet selectivity. ICES C. 1995/B18.

Holt, R.E., Jørgensen, C., 2015. Climate change in fish : effects of respiratory constraints on optimal life history and behaviour. Biol. Lett. 11, 20141032. https://doi.org/http://dx.doi.org/10.1098/rsbl.2014.1032

Hovgård, H., 1996. Effect of twine diameter on fishing power of experimental gill nets used in Greenland waters. Can. J. Fish. Aquat. Sci. 53, 1014-1017.

Hyder, K., Townhill, B., Anderson, L.G., Delany, J., Pinnegar, J.K., 2015. Can citizen science contribute to the evidence-base that underpins marine policy? Mar. Policy 59, 112-120. https://doi.org/10.1016/j.marpol.2015.04.022

Hyder, K., Weltersbach, M.S., Armstrong, M., Ferter, K., Townhill, B., Ahvonen, A., Arlinghaus, R., Baikov, A., Bellanger, M., Birzaks, J., Borch, T., Cambie, G., de Graaf, M., Diogo, H.M.C., Dziemian, Ł., Gordoa, A., Grzebielec, R., Hartill, B., Kagervall, A., Kapiris, K., Karlsson, M., Kleiven, A.R., Lejk, A.M., Levrel, H., Lovell, S., Lyle, J., Moilanen, P., 
Monkman, G., Morales-Nin, B., Mugerza, E., Martinez, R., O’Reilly, P., Olesen, H.J., Papadopoulos, A., Pita, P., Radford, Z., Radtke, K., Roche, W., Rocklin, D., Ruiz, J., Scougal, C., Silvestri, R., Skov, C., Steinback, S., Sundelöf, A., Svagzdys, A., Turnbull, D., van der Hammen, T., van Voorhees, D., van Winsen, F., Verleye, T., Veiga, P., Vølstad, J.H., Zarauz, L., Zolubas, T., Strehlow, H. V., 2018. Recreational sea fishing in Europe in a global context—Participation rates, fishing effort, expenditure, and implications for monitoring and assessment. Fish Fish. 19, 225-243. https://doi.org/10.1111/faf.12251

Hyder, K., Wright, S., Kirby, M., Brant, J., 2016. The role of citizen science in monitoring smallscale pollution events. Mar. Pollut. Bull. 0-1. https://doi.org/10.1016/j.marpolbul.2017.04.038

ICES, 2017. ICES DATRAS database [WWW Document].

Karr, J.R., 1981. Assessment of biotic integrity using fish communities. Fisheries 6, 21-27. https://doi.org/10.1577/1548-8446(1981)006<0021

Korpinen, S., Meski, L., Andersen, J.H., Laamanen, M., 2012. Human pressures and their potential impact on the Baltic Sea ecosystem. Ecol. Indic. 15, 105-114. https://doi.org/10.1016/j.ecolind.2011.09.023

Kosmala, M., Wiggins, A., Swanson, A., Simmons, B., 2016. Assessing data quality in citizen science. Front. Ecol. Environ. 14, 551-560. https://doi.org/10.1002/fee.1436

Kristensen, A.L.D., Støttrup, J.G., Andersen, S.K., Degel, H., 2014. Registrering af fangster i de danske kystområder med standardredskaber. Nøglefiskerrapport 2011-2013. DTU Aqua-raport nr. 286-2014.

Kristensen, L.D., Stenberg, C., Støttrup, J.G., Poulsen, L.K., Christensen, H.T., Dolmer, P., Landes, A., Røjbek, M., Thorsen, S.W., Holmer, M., Deurs, M. V., Grønkjær, P., 2015. Establishment of blue mussel beds to enhance fish habitats. Appl. Ecol. Environ. Res. 13. https://doi.org/10.15666/aeer/1303_783798 
Lotze, H.K., 2006. Depletion, Degradation, and Recovery Potential of Estuaries and Coastal Seas. Science (80-. ). 312, 1806-1809. https://doi.org/10.1126/science.1128035

Madsen, K.S., Højerslev, N.K., 2009. Long-term temperature and salinity records from the Baltic Sea transition zone. Boreal Environ. Res. 14, 125-131.

Martinsson, J., Nissling, A., 2011. Nursery area utilization by turbot (Psetta maxima) and flounder (Platichthys flesus) at Gotland, central Baltic Sea. Boreal Environ. Res. 16, 60-70.

McKinley, D.C., Miller-Rushing, A.J., Ballard, H.L., Bonney, R., Brown, H., Cook-Patton, S.C., Evans, D.M., French, R.A., Parrish, J.K., Phillips, T.B., Ryan, S.F., Shanley, L.A., Shirk, J.L., Stepenuck, K.F., Weltzin, J.F., Wiggins, A., Boyle, O.D., Briggs, R.D., Chapin, S.F., Hewitt, D.A., Preuss, P.W., Soukup, M.A., 2017. Citizen science can improve conservation science, natural resource management, and environmental protection. Biol. Conserv. 208, 15-28. https://doi.org/10.1016/j.biocon.2016.05.015

McPhee, D.., Leadbitter, D., Skilleter, G.., 2002. Swallowing the bait: is recreational fishing in Australia ecologically sustainable? Pacific Conserv. Biol. 8, 40-51.

Muus, B.J., 1967. The fauna of Danish estuaries and lagoons. Distribution and ecology of dominating species in the shallow reaches of the mesohaline zone. Meddelelser fra Danmarks Fiskeri- og Havundersøgelser, Bind 5, Nr. 1.

Muus, B.J., Nielsen, J.G., 2006. Havfisk og fiskeri i Nordvesteuropa, 6th ed. Gyldendal, Copenhagen, Denmark.

Natale, F., Carvalho, N., Paulrud, A., 2015. Defining small-scale fisheries in the EU on the basis of their operational range of activity The Swedish fleet as a case study. Fish. Res. 164, 286-292. https://doi.org/10.1016/j.fishres.2014.12.013

Neuman, E., Sandström, O., Thoresson, G., 1999. Guidelines for coastal fish monitoring. Natl. Board Fish. Inst. Coast. Res. Öregrund, Sweden 44. 
Newson, S.E., Moran, N.J., Musgrove, A.J., Pearce-Higgins, J.W., Gillings, S., Atkinson, P.W., Miler, R., Grantham, M.J., Baillie, S.R., 2016. Long-term change in spring and autumn migration phenology of common migrant breeding birds in Britain: results from large-scale citizen science bird recording schemes. Ibis (Lond. 1859). 158, 481-495. https://doi.org/10.1111/ibi.12367

O’Meara, T.A., Hillman, J.R., Thrush, S.F., 2017. Rising tides, cumulative impacts and cascading changes to estuarine ecosystem functions. Sci. Rep. 7, 10218. https://doi.org/10.1038/s41598017-11058-7

Olesen, H.J., Storr-Paulsen, M., 2015. Eel, cod and seatrout harvest in Danish recreational fishing during 2011. DTU Aqua Rep. 253-2012 28 pp.

Olsson, J., Bergström, L., Gårdmark, A., 2012. Abiotic drivers of coastal fish community change during four decades in the Baltic Sea. ICES J. Mar. Sci. 69, 961-970.

Poulsen, L.K., Christensen, H.T., Stenberg, C., Kristensen, L.D., Thorsen, S.W., Røjbek, M., Holmer, M., Landes, A., Andersen, S.K., Dolmer, P., Geitner, K., Gram, V., Holm, N., Holmer, M., Knudsen, J., Knudsen, M., Støttrup, J.G., 2012. Slutrapport for Projekt BioRev 2010-2012. DTU Aqua-rapport 251-2012.

Seitz, R.D., Wennhage, H., Bergström, U., Lipcius, R.N., Ysebaert, T., 2014. Ecological value of coastal habitats for commercially and Ecologically Important Species. ICES J. Mar. Sci. 71, 648-665.

Skóra, K.E., Stolarski, J., 1996. Neogobius melanostomus (Pallas 1811) a new immigrant species in Baltic Sea, in: Styczynska-Jurewicz, E. (Ed.), Estuarine Ecosystems and Species. Proc 2nd Int Estuary Symp, Gda'nsk, 18-22 October 1993. Iss Mar Biol Centre Gdynia 1, pp. 101-108.

Souza, A.T., Dias, E., Nogueira, A., Campos, J., Marques, J.C., Martins, I., 2013. Population ecology and habitat preferences of juvenile flounder Platichthys flesus (Actinopterygii: 
Pleuronectidae) in a temperate estuary. J. Sea Res. 79, 60-69. https://doi.org/10.1016/j.seares.2013.01.005

Sparrevohn, C.R., Nicolajsen, H., Kristensen, L., Støttrup, J.G., 2009. Registrering af fangster i de danske kystområder med standardredskaber fra 2005-2007 Nøglefiskerrapporten 2005-2007 78.

Støttrup, J.G., Andersen, S.K., Kokkalis, A., Christoffersen, M., Pedersen, E.M.F., 2017. Registrering af fangster i de danske kystområder med standardredskaber Nøglefiskerrapport 2014-2016 Registrering af fangster i de danske kystområder med standardredskaber Nøglefiskerrapport for 2014-2016. DTU Aqua-rapport nr. 320-2017.

Støttrup, J.G., Lund, H.S., Kindt-Larsen, L., Egekvist, J., Munk, P., Stenberg, C., 2014. KYSTFISK I . Kortlægning af de kystnære fiske- bestandes udvikling på basis af fiskernes egne observationer i perioden fra 1980’ erne til 2013. DTU Aqua Rep. 278-2014 52.

Støttrup, J.G., Sparrevohn, C.R., Nicolajsen, H., Kristensen, L.D., 2012. Registrering af fangster i de danske kystområder med standardredskaber. Nøglefiskerrapporten for årene 2008-2010. DTU Aqua Rep. 252, 95.

Strehlow, H. V., Schultz, N., Zimmermann, Christopher Hammer, C., 2012. Cod catches taken by the German recreational fishery in the western Baltic Sea, 2005-2010: implications for stock assessment and management. ICES J. Mar. Sci. 69, 1769-1780.

Teal, L.R., van Hal, R., van Kooten, T., Ruardij, P., Rijnsdorp, A.D., 2012. Bio-energetics underpins the spatial response of North Sea plaice (Pleuronectes platessa L.) and sole (Solea solea L.) to climate change. Glob. Chang. Biol. 18, 3291-3305. https://doi.org/10.1111/j.13652486.2012.02795.x

Toivonen, A.L., Roth, E., Navrud, S., Gudbergsson, G., Appelblad, H., Bengtsson, B., Tuunainen, P., 2004. The economic value of recreational fisheries in Nordic countries. Fish. Manag. Ecol. 
691 Underwood, A.J., Chapman, M.G., 2006. Conservation of coastal organisms depends on scientific 692 realism, not community “ monitoring ” 20-37.

693 Vann-Sander, S., Clifton, J., Harvey, E., 2016. Can citizen science work? Perceptions of the role 694 and utility of citizen science in a marine policy and management context. Mar. Policy 72, 82695 93. https://doi.org/10.1016/j.marpol.2016.06.026

696 Vasconcelos, R.P., Reis-Santos, P., Fonseca, V., Maia, A., Ruano, M., França, S., Vinagre, C., 697 Costa, M.J., Cabral, H., 2007. Assessing anthropogenic pressures on estuarine fish nurseries 698 along the Portuguese coast: A multi-metric index and conceptual approach. Sci. Total Environ. 699 374, 199-215. https://doi.org/10.1016/j.scitotenv.2006.12.048

700 Wood, S., 2006. Generalized Additive Models: An Introduction with R. CRC Press. 701 702 
703 Table 1. List of fish species caught in the gill nets (G) and fyke nets (F) over the period 2005-2016

704 and 2002-2016 respectively.

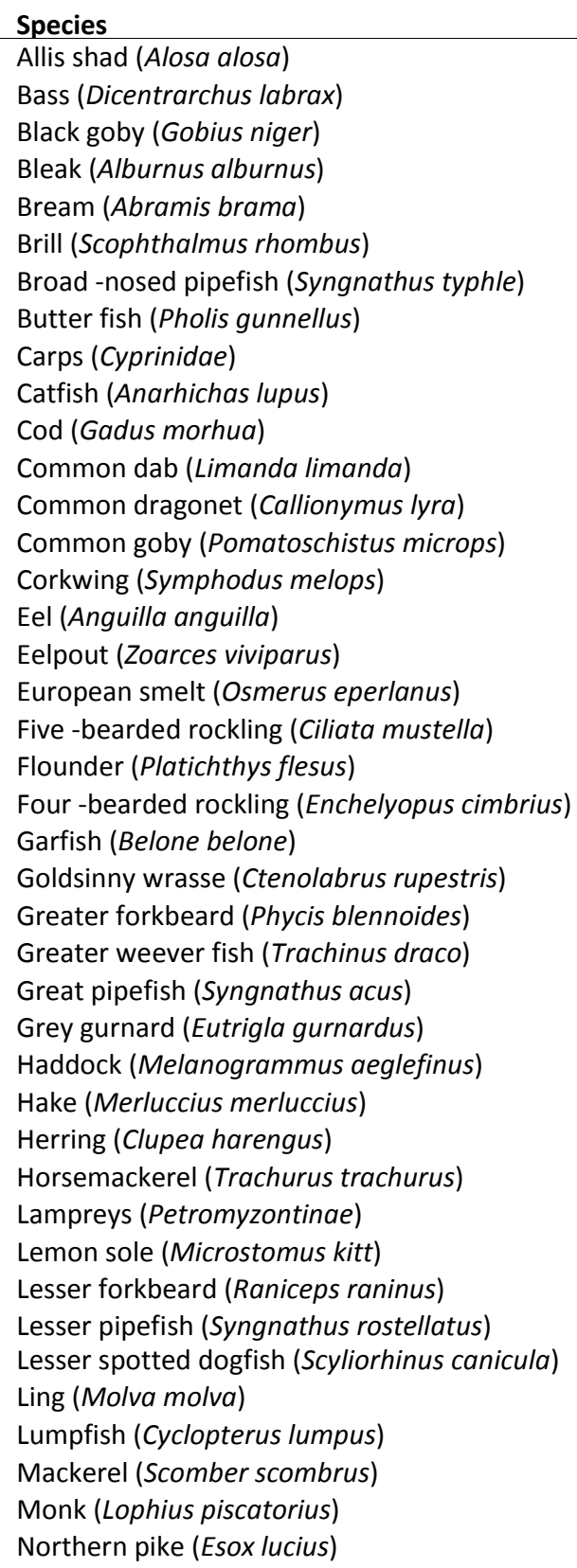

\begin{tabular}{|c|c|}
\hline Gear & Species \\
\hline$G, F$ & Perch (Perca fluviatilis) \\
\hline$G, F$ & Pikeperch (Sander lucioperca) \\
\hline $\mathrm{F}$ & Plaice (Pleuronectes platessa) \\
\hline $\mathrm{F}$ & Pogge(armed bullhead) (Agonus cataphractus) \\
\hline$G, F$ & Pollack (Pollachius pollachius) \\
\hline$G, F$ & Poor -cod (Trisopterus minutus) \\
\hline$G, F$ & Powan/European whitefish (Coregonus lavaretus) \\
\hline $\mathrm{F}$ & Rainbow trout (Oncorhynchus mykiss) \\
\hline $\mathrm{F}$ & Red gurnard (Trigla lucerna) \\
\hline $\mathrm{F}$ & Roach (Rutilus rutilus) \\
\hline $\mathrm{G}, \mathrm{F}$ & Round goby (Neogobius melanostomus) \\
\hline $\mathrm{G}, \mathrm{F}$ & Rudd (Scardinius erythrophthalmus) \\
\hline $\mathrm{G}, \mathrm{F}$ & Saithe (Pollachius virens) \\
\hline $\mathrm{F}$ & Salmon (Salmo salar) \\
\hline $\mathrm{F}$ & Sand eels (Ammodytes) \\
\hline $\mathrm{G}, \mathrm{F}$ & Sand goby (Pomatoschistus minutus) \\
\hline $\mathrm{G}, \mathrm{F}$ & Sculpin (Myoxocephalus scorpius) \\
\hline $\mathrm{G}, \mathrm{F}$ & Sculpin (Triglops murrayi) \\
\hline $\mathrm{F}$ & Sea lamprey (Petromyzon marinus) \\
\hline $\mathrm{G}, \mathrm{F}$ & Sea(ninespine) -stickleback (Pungitius pungitius) \\
\hline $\mathrm{F}$ & Sea scorpion (Taurulus bubalis) \\
\hline $\mathrm{G}, \mathrm{F}$ & Sea trout (Salmo trutta) \\
\hline $\mathrm{F}$ & Shanny (Blennius pholis) \\
\hline $\mathrm{F}$ & Smallmounthed wrasse (centrolabrus exletus) \\
\hline $\mathrm{G}, \mathrm{F}$ & Snake pipefish (Entelurus aequoreus) \\
\hline $\mathrm{F}$ & Sole (Solea solea) \\
\hline G & Sprat (Sprattus sprattus) \\
\hline$G, F$ & Straightnose pipefish (Nerophis ophidion) \\
\hline $\mathrm{F}$ & Tench (Tinca tinca) \\
\hline $\mathrm{G}, \mathrm{F}$ & Ten spined stickleback (Spinachia spinachia) \\
\hline$G, F$ & Thick lipped mullet (Mugil cephalus) \\
\hline $\mathrm{F}$ & Three -spined stickleback (Gasterosteus aculeatus) \\
\hline $\mathrm{G}, \mathrm{F}$ & Topknot (Zeugopterus punctatus) \\
\hline $\mathrm{F}$ & Transperant goby (Aphia minuta) \\
\hline $\mathrm{F}$ & Tub gurnard (Aspitrigla cuculus) \\
\hline $\mathrm{F}$ & Turbot (Psetta maxima) \\
\hline $\mathrm{F}$ & Tusk (Brosme brosme) \\
\hline$G, F$ & Twaite shad (Alosa fallax) \\
\hline$G, F$ & Whiting (Merlangius merlangus) \\
\hline $\mathrm{F}$ & Witch (Glyptocephalus cynoglossus) \\
\hline$G, F$ & Wrasses (Labridae sp.) \\
\hline
\end{tabular}


Figure Captions

Fig. 1. Number of fishing instances undertaken using gill nets and fyke nets during the period 2005-2016.

Fig. 2. Map of Denmark showing area divisions (light grey areas with area numbers) and fishing positions (black dots) where either fyke nets (a) or gill nets (b) were deployed. Positions shown are those that were active at least one year since 2002. The island shown inset is Bornholm, situated further to the east in the southern Baltic Sea. 1. Open west coast, 2. Northern Limfjord, 3. Skive Fjord and Lovns Broad, 4. Western Limfjord, 5. Nissum Fjord, 6. Ringkøbing Fjord, 7. Bornholm, 8. Aalborg Bay and Læs $\varnothing, 9$. Mariager and Horsens Fjords, 10. Aarhus Bay, 11. Vejle Fjord, 12. Odense Fjord, 13. Little Belt, 14. Fyns archiplelago, 15. Sejerø Bay, 16. Great Belt and Kerteminde Fjord, 17. Smålandsfarvandet, 18. Fehmarn Belt, 19. Roskilde Fjord and Isefjord, 20. Sound and Faxe Bay, and 21. Præst $\varnothing$ Fjord.

Fig. 3. Total catch, in number of individuals, for the five most abundant species caught in gill nets $(a, c)$ and fyke nets (b, d) in $2005(a, b)$ and 2016 (c, d) before and after the invasion of the round goby in the western Baltic Sea area.

Fig. 4. Annual average of catch per unit effort (CPUE; numbers per $12 \mathrm{~h}$, error bars: $95 \% \mathrm{Cl}$ ) of flounder (Platichthys flesus) in gill nets (2005-2016). Smålandsfarvandet is not presented because it has too few data points.

Fig. 5. Annual average catch per unit effort (CPUE; numbers per $48 \mathrm{~h}$, error bars: $95 \% \mathrm{Cl}$ ) of flounder (Platichthys flesus) in fyke nets (2002-2016). Nissum Fjord and Ringkøbing Fjord are not presented because they have too few data points.

Fig. 6. Annual average catch per unit effort (CPUE, error bars: one standard error) in numbers per $12 \mathrm{~h}$ of flounder (Platichthys flesus) caught in gill nets in Roskilde Fjord and Isefjord (a), and Sejerø Bay (b) with linear regressions (mean: solid line, 95\% confidence interval: shaded area). Weekly CPUE of flounder in Roskilde Fjord and Isefjord (c) and Sejerø Bay (d) with fitted Generalised Additive Mixed Model (total mean: solid line, trend: dashed line, $95 \% \mathrm{Cl}$ : shaded area). High CPUE values are omitted; their positions are denoted with vertical lines in the top of the plots.

Fig. 7. Monthly average catch per unit effort (CPUE; numbers per $12 \mathrm{~h}$ ) of flounder (Platichthys flesus) caught in gill nets in Roskilde Fjord and Isefjord (solid line) and Sejerø Bay (dashed line) during the last three years (above) with local temperature from the provided loggers (below). 
$740 \quad$ Figure 1.

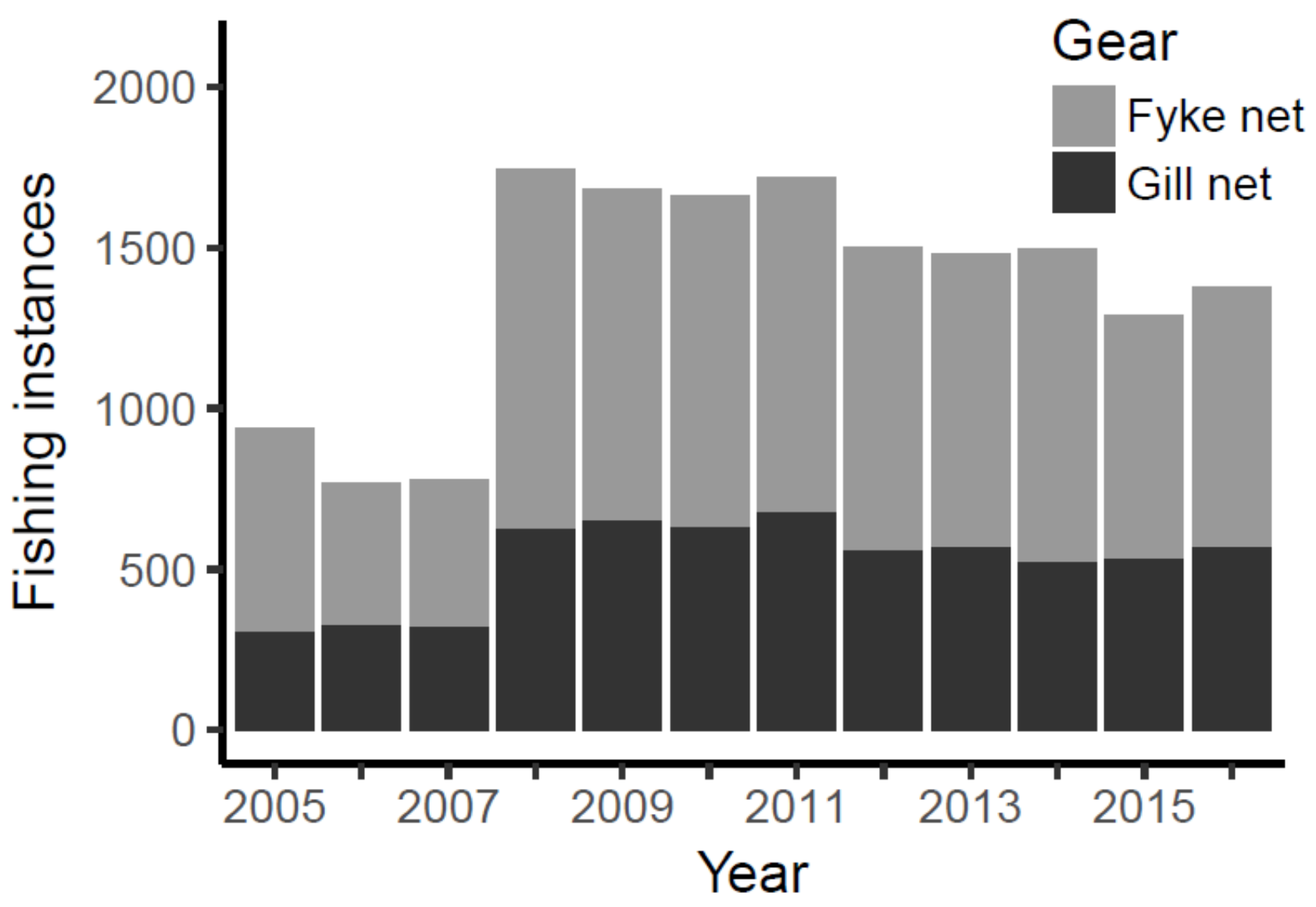


744 Figure 2.

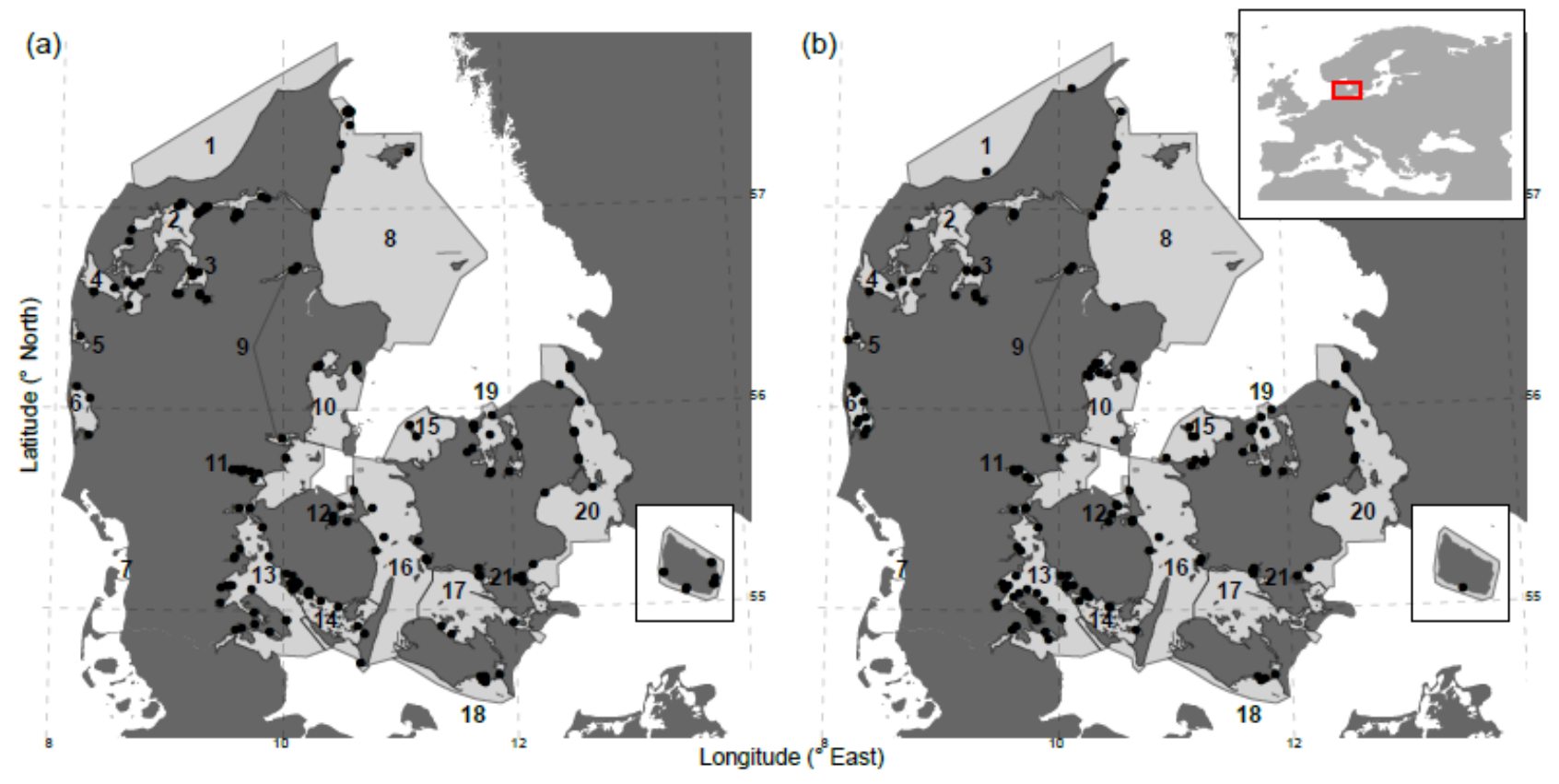

746 
747 Figure 3.

748

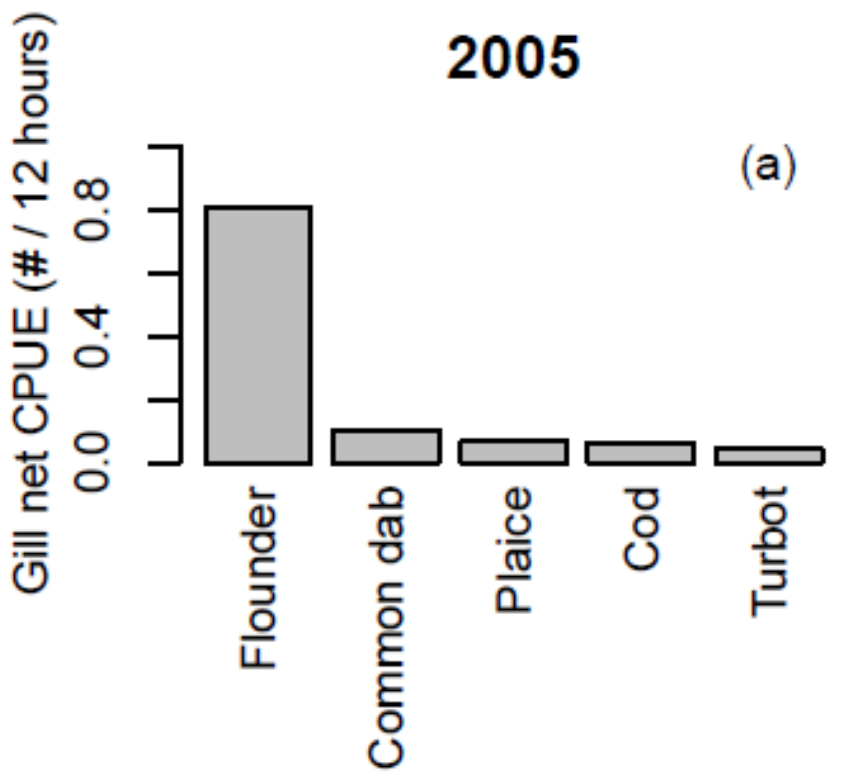

2016
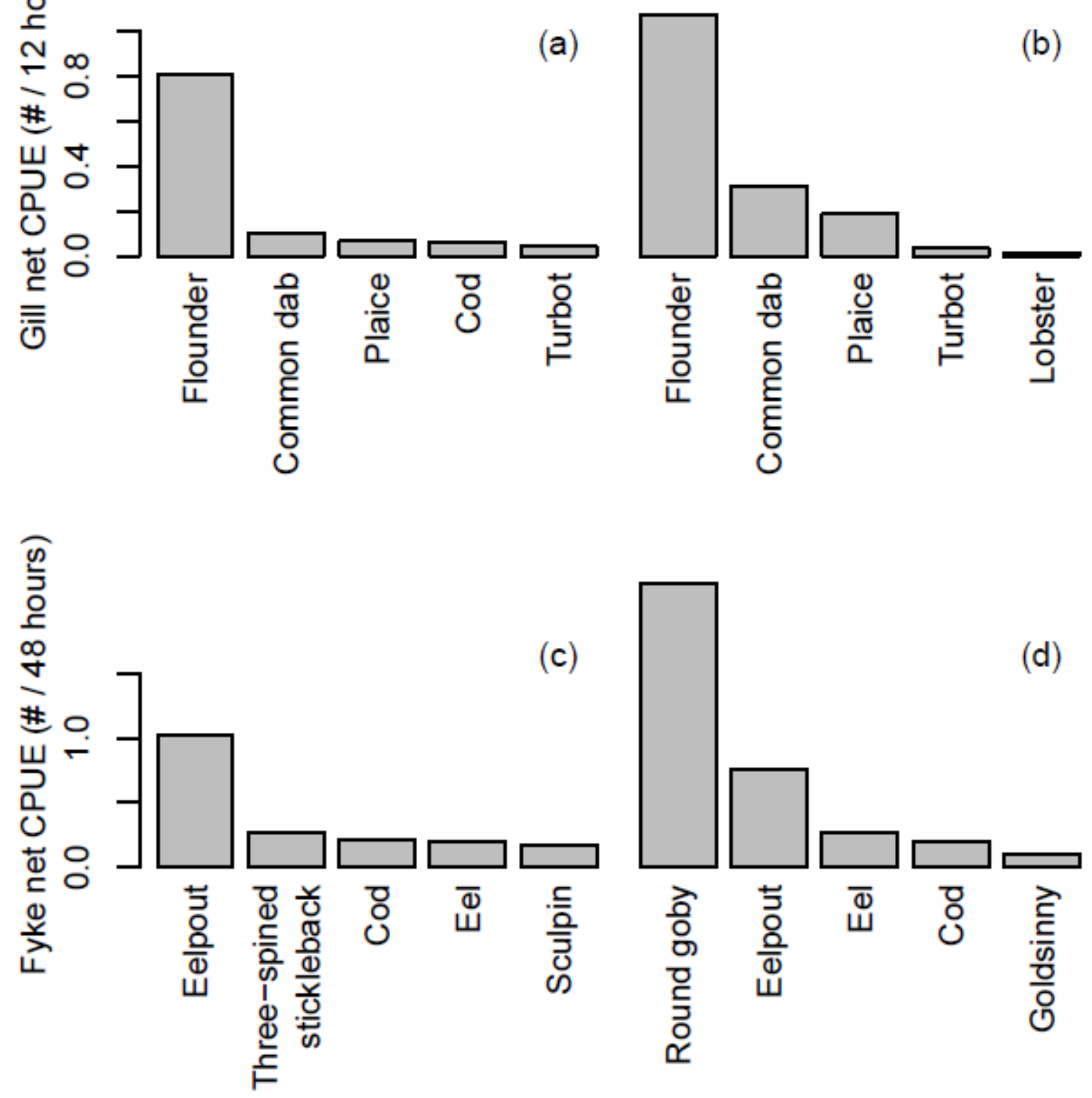
Figure 4.

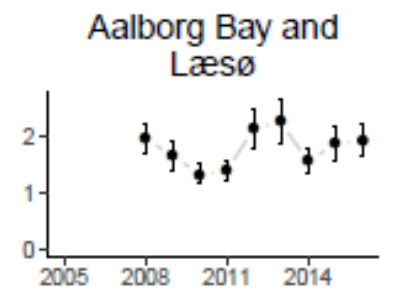

Aarhus Bay

Bornholm

Fehmarn Belt
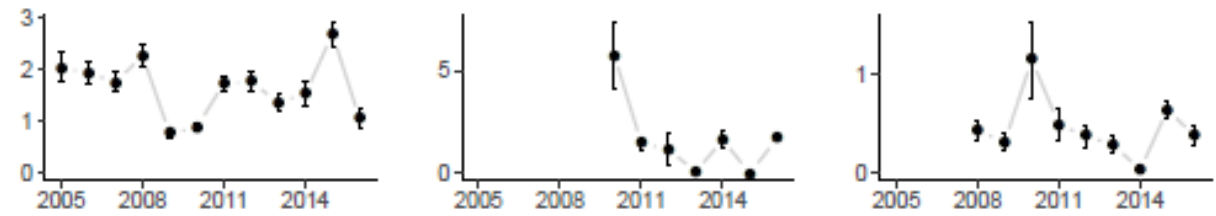

Fyns

archiplelago

Great Belt and Kerteminde Fjord

Little Belt

Mariager and Horsens Fjords
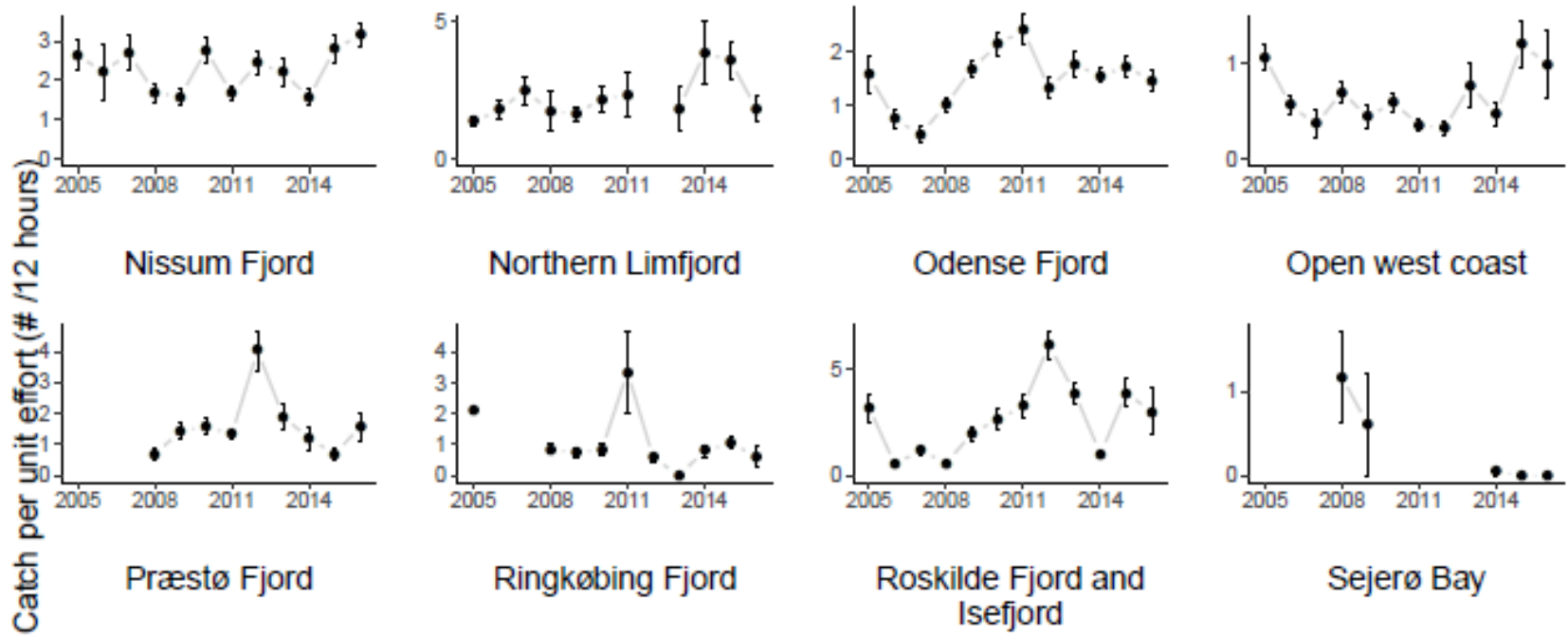

Northern Limfjord

Odense Fjord

Open west coast
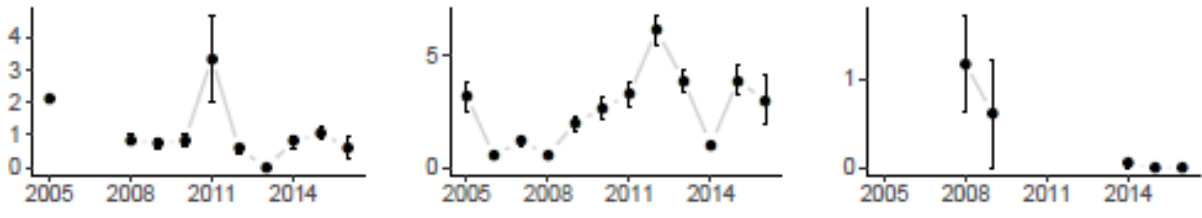

Roskilde Fjord and Isefjord
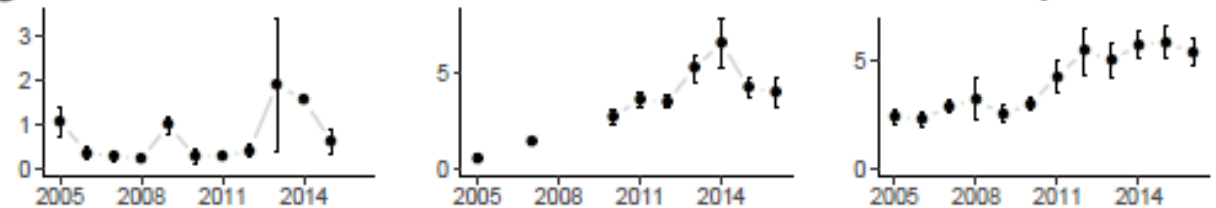

Sejerø Bay

Ringkøbing Fjord

Skive Fjord and Lovns Broad

Sound and Faxe Bay
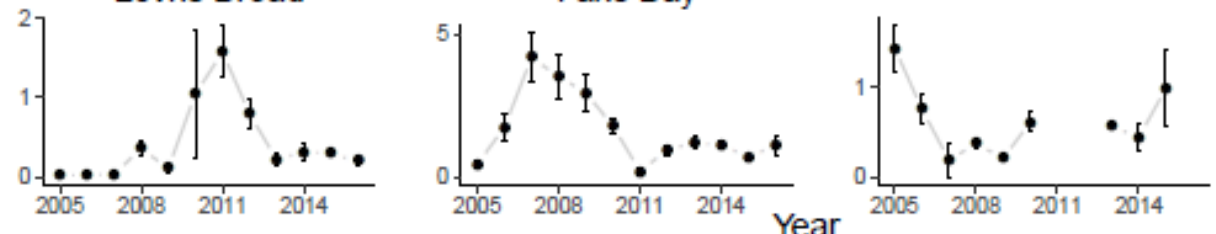

Western Limfjord

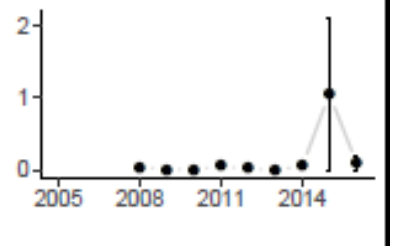


Figure 5.
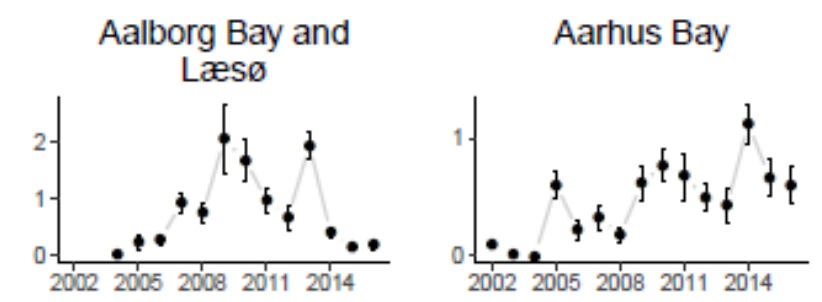

Bornholm

Fehmarn Belt

Fyns

archiplelago

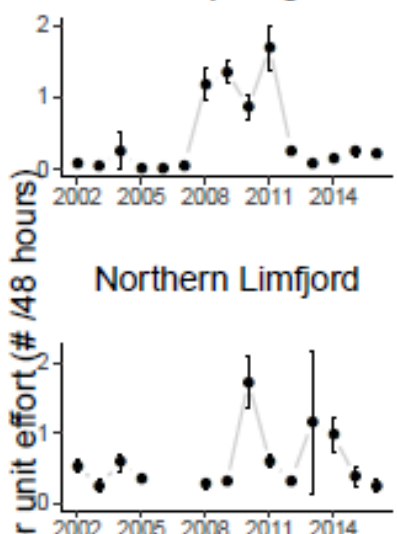
20022005200820112014

造 Sejerø Bay

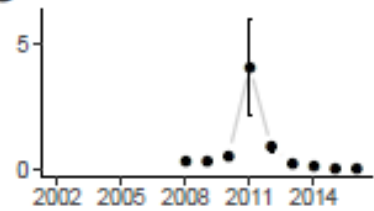

Vejle Fjord

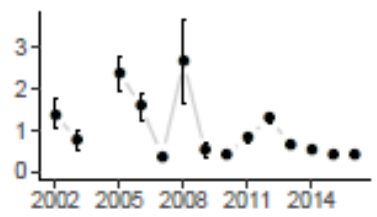

Great Belt and Kerteminde Fjord

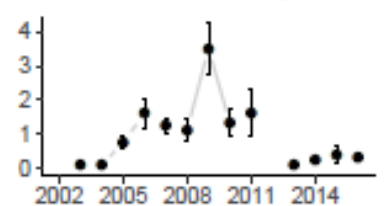

Odense Fjord

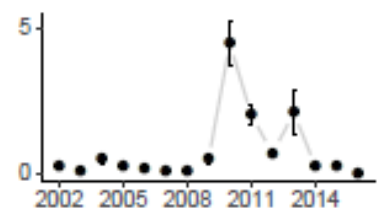

Skive Fjord and Lovns Broad

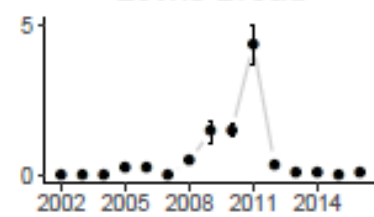

Western Limfjord

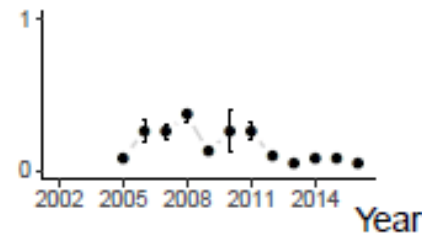

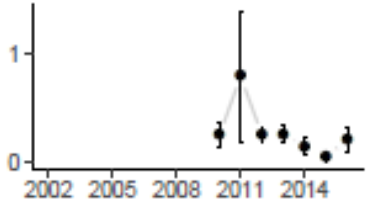

Little Belt

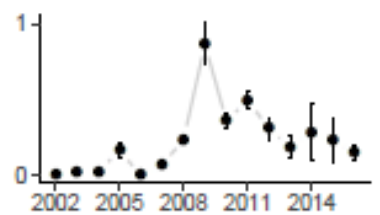

Præstø Fjord

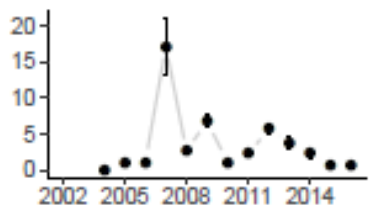

Smålandsfarvandet

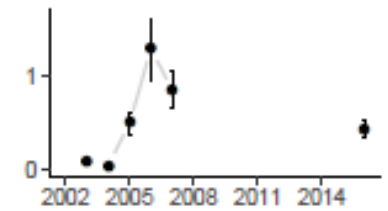

Sound and Faxe Bay

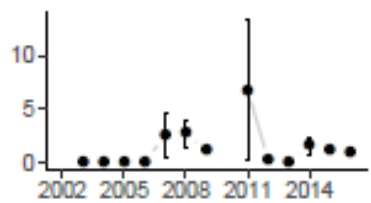


Figure 6.

(a)

(b)
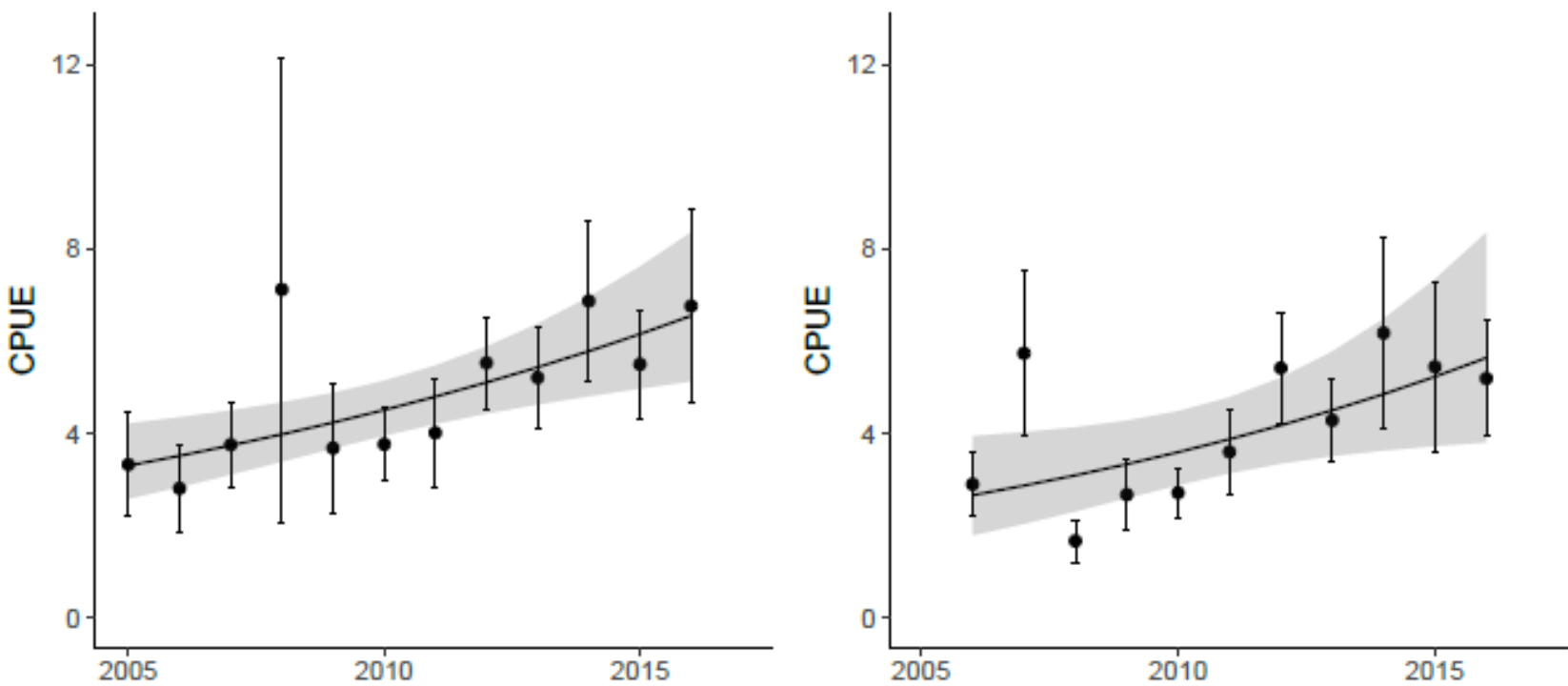

(c)

(d)
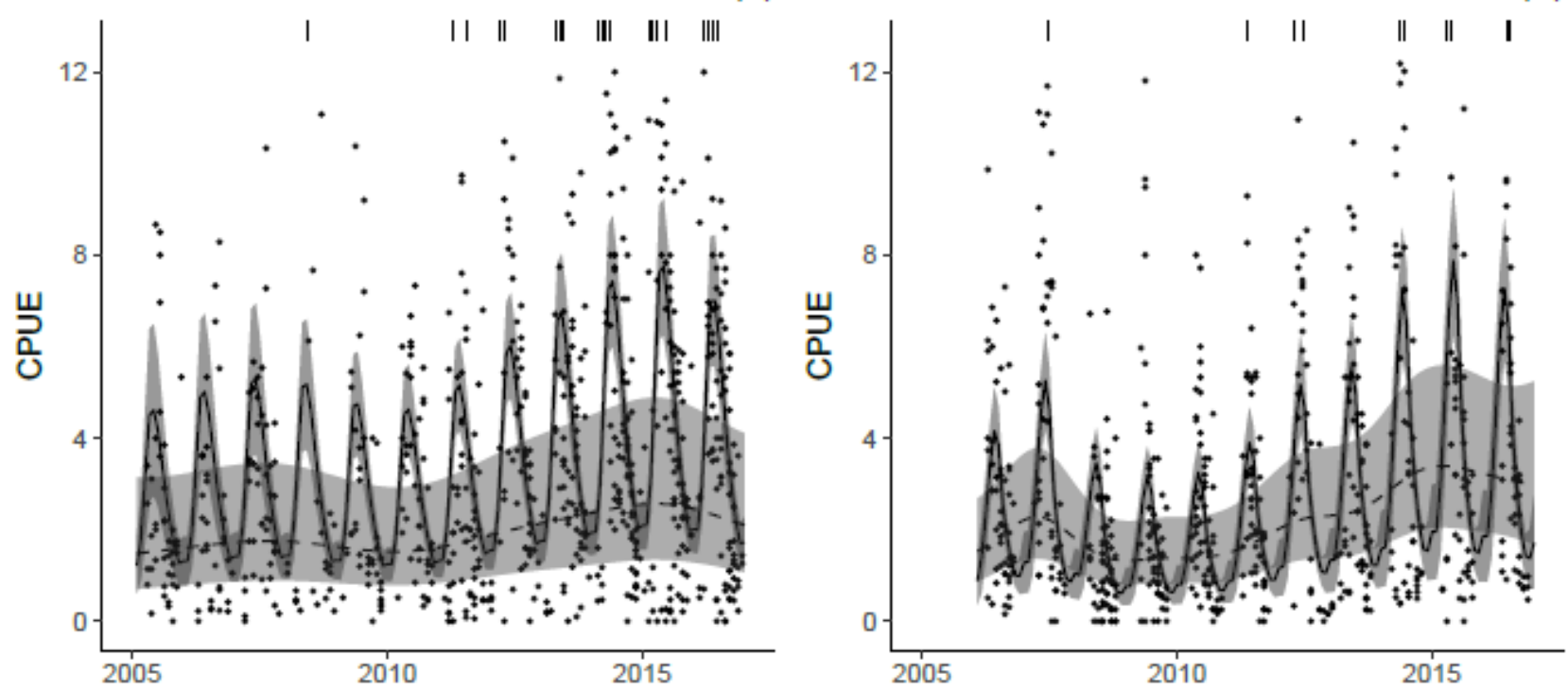
$770 \quad$ Figure 7.
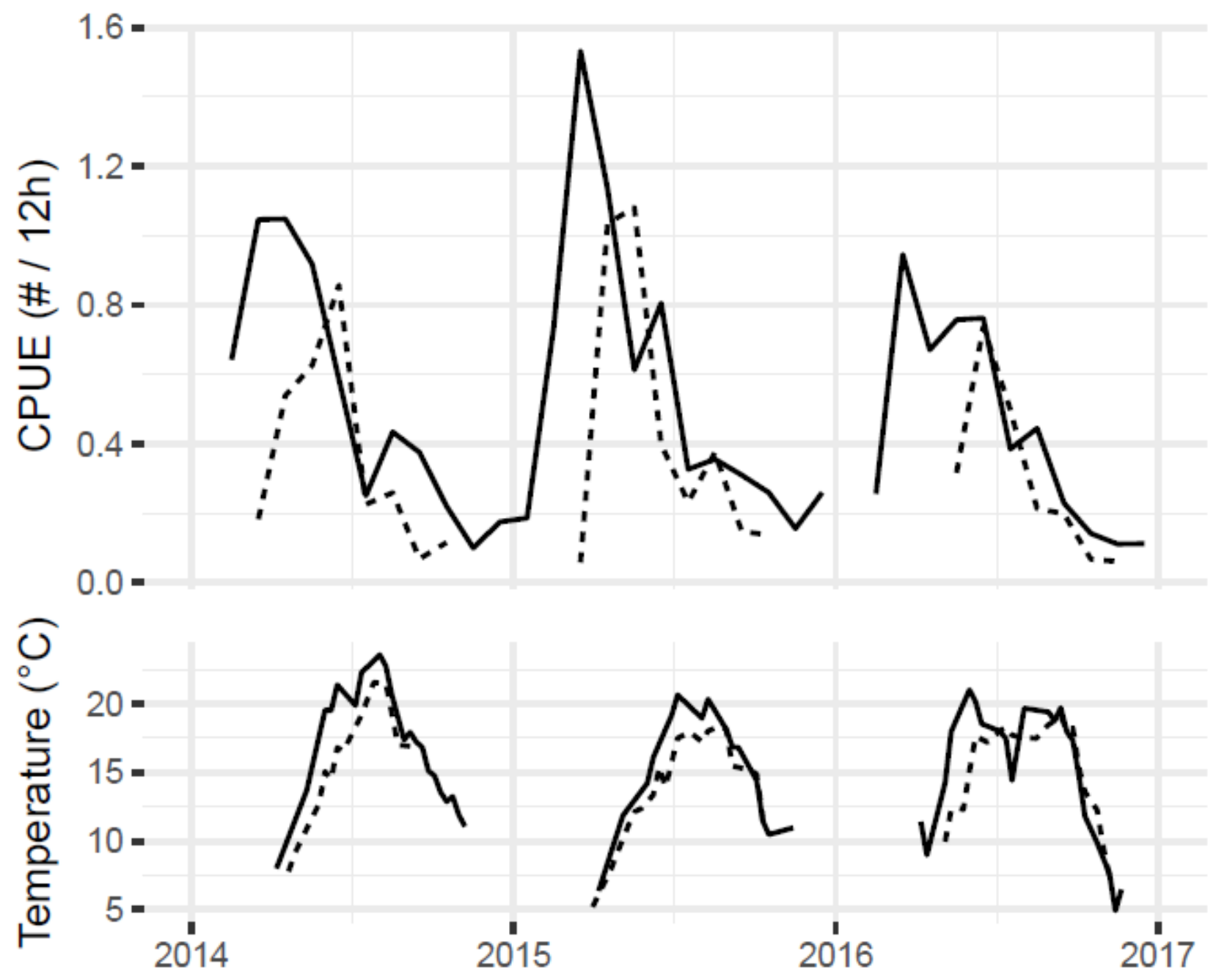

- Roskilde Fjord and Isefjord ---. Sejerø Bay 